\title{
Chemical composition of the cotyledons and seed coat and nutritional value of whole and hulled seeds of yellow lupin
}

\section{Z. Zduńczyk', J. Juśkiewicz', S. Frejnagel', Marianna Flis², and Irena Godycka ${ }^{1}$}

'Division of Food Science, Centre for Agrotechnology and Veterinary Sciences

Polish Academy of Sciences,

Tuwima 10, 10-718 Olsztyn, Poland

${ }^{2}$ Institute of Animal Nutrition and Feed Management, Olsztyn Academy of Agriculture and Technology,

Oczapowskiego S, 10-718 Olsztyn, Poland

(Received 27 April 1994; accepted 12 May 1994)

\section{ABSTRACT}

Removing of the seed coat by mechanic separation of fraction crushed yellow lupin var. Juno seeds increased the protein content from 41.6 to $52.4 \%$ and decreased dietary fibre content from 28.4 to $15.9 \%$ as compared to whole seeds. The chemical composition, the content of alkaloids $(0.15 \%)$, dietary fibre $(15.9 \%)$ and $\alpha$-galactosides $(11.66 \%)$ of hulled seeds was similar to the cotyledons obtained by manual dehulling. Due to a higher content of some essential amino acids, mainly tryptophan and lysine in the seed coat, the hulling lowered the value of EAAI index from 60.0 in whole seeds to 58.9 in hulled seeds and 56.6 in cotyledons. Substitution of wholc lupin-meals with hulled seeds in rat diets did not increase digestibility of crude protein ( 86.8 and $86.2 \%$, respectively) or the protein efficiency ratio (2.02 and 2.05 , respectively).

KEY WORDS: lupin, cotyledons, seed coat, whole and hulled seeds, chemical composition, nutritional value

\section{INTRODUCTION}

Percentage of the seed coat in whole lupin seeds may decrease their nutritional value. Only in some varieties of Lupinus angustifolius and Lupinus albus which seeds are large the seed coat does not exceed $20 \%$ whereas in those of Lupinus luteus it usually exceeds $25 \%$ of the seed weight (Brillouet and Riochet, 1983; 
Pastuszewska, 1985). The seed coat of lupin contains 65 to $80 \%$ of low digestible carbohydrates including fibres (Feldheim, 1990; Pastuszewska, 1985). For this reason almost half of the lupin seed energy is released as late as in the large intestine of monogastric animals (Taverner et al., 1983) where fibre is digested (Aguilera et al., 1985). Utilization of energy absorbed in this part of the digestive tract is, however, low which reduced the value of net energy in lupin seeds (Just et al., 1983). This justifies the attempts to increase the nutritional value of lupin seeds through hulling.

The aim of the study was to determine the chemical composition of the cotyledons and seed coat of $\mathrm{cv}$. Juno yellow lupin seeds and to evaluate the effect of hulling on digestibility and nutritional value of protein for rat.

\section{MATERIAL AND METHODS}

Whole and hulled seeds of $\mathrm{cv}$. Juno yellow lupin were investigated. Hulling was conducted on a semiindustrial scale using a crusher and set of sieves (Flis et al., 1993). Manually separated samples of the cotyledons and seed coat were taken for evaluation of mechanic hulling efficiency.

The nutrients composition of seeds and their fractions was determined by standard methods (AOAC, 1990). Phytates content were determined according to Oberleas et al. in Rutkowska's modification (1981). Gross energy was measured with a calorimeter with an adiabatic bomb. Alkaloids were determined according to Skolik and Wiewiórowski (1959), saccharose and $x$-galactosides using HPLC following samples preparations according to Muzquiz et al. (1992). Minerals were analysed with the atomic absorption spectrophotometry using spectro-photometer PXE UNICAM SP 2900. Amino acid composition was determined with an automatic analyser Beckman 6300 following samples preparation according to Hirs (1954). Sulphur amino acids hydrolysis was conduted according to Schram et al. (1954). Tryptophan was measured spectrophotometrically according to Opieńska-Blauth et al. (1963).

The experiment was carried out on Wistar rats from Ifz:JAZ outbred herd. Nutritional value of protein of whole and hulled lupin seeds given as a sole protein source was estimated. Diets prepared according to Eggum (1973) contained about $10 \%$ crude protein supplemented with Dl-methionine $(0.15 \%)$ and lysine $(0.1 \%)$. Control group was fed casein supplemented with Dl-methionine $(0.15 \%)$. Diets contained also soya bean and sunflower oil $(8 \%)$, and standard amount (4\% and $1 \%$ ) of mineral mixture (NRC Standard, 1976) and vitamin mixture (AOAC, 1975).

The rats were housed individually in metabolic cages as described by Eggum (1973) at a room temperature $22-23^{\circ} \mathrm{C}$ and relative humidity of 50 to $70 \%$. Crude 
protein digestibility was determined in 6 animals from each group with initial body weight $76.2 \pm 1.40 \mathrm{~g}$. Coefficients of true digestibility were computed regarding metabolic nitrogen, which was estimated according to Rakowska et al. (1978). Protein efficiency ratio (PER) was determined in groups of 4 males and 3 females of initial age 27-30 days and average body weight $57.9 \pm 2.3 \mathrm{~g}$. Following PER determination, the rats were decapitated and weight of the liver and empty small intestine was measured.

\section{RESULTS AND DISCUSSION}

The content of nutrients (Table 1) in the seeds was similar to the Polish varieties of yellow lupin analysed by Matyka et al. (1985) and Pastuszewska (1985). Mechanic and manual removing of the seed coat resulted in an increase in protein content from 41.4 to 52.4 and $54.8 \%$, respectively. Similar protein content in the cotyledons of yellow lupin seeds $(52.8 \%)$ was reported by Brillouet and Riochet (1983). Alkaloids content in whole seeds $(1.26 \mathrm{~g} / \mathrm{kg})$ was characteristic for the "sweet" varieties of yellow lupin (Matyka et al., 1985; Muzquiz et al., $1989)$, whereas phytates content $(11.0 \mathrm{~g} / \mathrm{kg})$ was lower than that reported by Muzquiz et al. (1989). Nutrients content as well as gross energy, alkaloids and phytates content (Table 1) in hulled seeds was similar to that in lupin cotyledons. This indicates that mechanic hulling resulted in removing of almost whole seed coat. The seed coat shared $22.55 \%$ of seed weight and, besides dietary fibre $(80.1 \%)$, it contained small amounts of antinutritional compounds (alkaloids and phytates). The percentage of the seed coat determined in Juno variety seeds can be considered as relatively low. Brillouet and Riochet (1983) analysed the

TABLE 1

Chemical composition of whole and hulled seeds, cotyledons and hulls from yellow lupin

\begin{tabular}{llcccr}
\hline Ingredient & & Whole seeds & Hulled seeds & Cotyledons & Hulls \\
\hline Dry matter & $\%$ & 90.56 & 91.48 & 91.68 & 90.75 \\
Ash & $\%$ & 3.70 & 4.26 & 4.34 & 2.47 \\
Crude protein $^{\prime} \%$ & 41.36 & 52.44 & 54.81 & 5.31 \\
Ether extract & $\%$ & 5.74 & 6.94 & 7.16 & 1.01 \\
Crude fibre & $\%$ & 12.72 & 3.15 & 1.71 & 49.38 \\
N-free extractives & $\%$ & 27.04 & 24.69 & 23.66 & 32.58 \\
Gross energy & $\mathrm{MJ} / \mathrm{kg}$ & 19.57 & 19.95 & 19.73 & 16.60 \\
Total alkaloids & $\mathrm{g} / \mathrm{kg}$ & 1.26 & 1.47 & 1.43 & 0.10 \\
Phytates & $\mathrm{g} / \mathrm{kg}$ & 9.60 & 11.03 & 12.17 & 0.60 \\
\hline
\end{tabular}

'Determined after acid hydrolysis of samples 
seeds of other yellow lupin variety which contained the seed coat as much as $27.2 \%$.

The content of minerals in whole seeds was close to the average values of Polish yellow lupin (Matyka et al., 1985). Analysed by Donovan et al. (1991) seeds of two white lupin varieties contained similar Ca amounts, less P and $\mathrm{Mg}$, and less, and much diversified, amount of microelements. In our experiments hulling resulted in $\mathrm{Ca}, \mathrm{Na}$ and $\mathrm{Fe}$ reduction, and in an increase in elements $(\mathrm{P}, \mathrm{Zn}$, $\mathrm{Cu}, \mathrm{Mn}$ ) which are scarce in the seed coat (Table 2). Hulling of seeds evidently lowered the percentage of fibre components with the highest (4-fold) loss of the fraction determined in the Weende analysed as crude fibre (Table 3). When

TABLE 2

Mineral composition of whole and hulled seeds and their fractions

\begin{tabular}{llcccc}
\hline Mineral & & Whole seeds & Hulled seeds & Cotyledons & Hulls \\
\hline $\mathrm{Ca}$ & $\mathrm{g} / \mathrm{kg}$ & 2.08 & 1.46 & 1.44 & 3.91 \\
$\mathrm{P}$ & $\mathrm{g} / \mathrm{kg}$ & 6.07 & 6.69 & 7.06 & 2.70 \\
$\mathrm{Na}$ & $\mathrm{g} / \mathrm{kg}$ & 0.68 & 0.40 & 0.52 & 0.96 \\
$\mathrm{Mg}$ & $\mathrm{g} / \mathrm{kg}$ & 2.15 & 2.39 & 2.16 & 1.84 \\
$\mathrm{Fe}$ & $\mathrm{mg} / \mathrm{kg}$ & 69.3 & 55.9 & 54.7 & 113.9 \\
$\mathrm{Zn}$ & $\mathrm{mg} / \mathrm{kg}$ & 74.6 & 89.1 & 91.8 & 13.5 \\
$\mathrm{Cu}$ & $\mathrm{mg} / \mathrm{kg}$ & 10.3 & 11.7 & 11.9 & 2.5 \\
$\mathrm{Mn}$ & $\mathrm{mg} / \mathrm{kg}$ & 80.7 & 82.9 & 87.1 & 65.5 \\
\hline
\end{tabular}

TABLE 3

Fibre fraction and $\alpha$-galactosides content

\begin{tabular}{lccccc}
\hline Ingrcdient & & Whole sceds & Hulled secds & Cotylcdons & Hulls \\
\hline Fibre: & & & & & \\
- crude (CF) & $\%$ & 12.72 & 3.15 & 1.77 & 49.38 \\
- acid detcrgent & & & & & \\
$\quad$ (NDF) & $\%$ & 16.24 & 4.61 & 3.12 & 63.45 \\
- neutral detergent & & & & & \\
$\quad$ (NDF) & $\%$ & 19.80 & 6.96 & 4.79 & 73.09 \\
- dietary (DF) & $\%$ & 28.40 & 15.86 & 13.27 & 80.13 \\
Saccharose & $\%$ & 1.09 & 1.05 & 1.01 & $\mathrm{x}$ \\
x-galactosides: & & & & & \\
- raffinose & $\%$ & 2.18 & 2.15 & 2.13 & $\mathrm{x}$ \\
- stachyose & $\%$ & 6.85 & 6.79 & 6.80 & $\mathrm{x}$ \\
- verbascose & $\%$ & 2.84 & 2.72 & 2.79 & $\mathrm{x}$ \\
- total & $\%$ & 11.87 & 11.66 & 11.72 & $\mathrm{x}$ \\
\hline
\end{tabular}

$\mathrm{x}-$ not determined 
enzymatic method was employed as the most suitable for measuring non-digestible cell wall components, it was found that hulled seeds, like cotyledons, contained considerable amounts of dietary fibre (DF) (respectively $15.9 \%$ and $13.3 \%$ ). Also in the work by Brillouet and Riochet (1983) the cotyledons of lupin seeds with high coat proportion (average $27.2 \%$ ) contained over $12 \%$ dry matter of cell wall polysaccharides. Thus, although dietary fibre removed from the seed coat made over $80 \%$, more than one third of the total seed DF content remained in the cotyledons.

The content of saccharose (1.05\%) and $\alpha$-galactosides (11.9\%) in whole seeds (Table 3) was similar to obtained earlier for the same variety by Flis (1993). A similar content of $\alpha$-galactosides $(10.1 \%$ ) was found by Trugo et al. (1988) who analysed seeds of other variety of yellow lupin seeds. Other autors quoted by Saini (1989) found higher content of total $\alpha$-galactosides, mainly stachyose $(11.8 \%)$. On the other hand, on analysing the cotyledons of Australian varieties of Lupinus angustifolius, Evans and Cheung (1993) found much lower content of oligosaccharides $(7.4-8 \%)$ and as little as $0.3-0.4 \% \alpha$-galactosides in the seed coat.

Protein in the lupin seeds had a low methionine $(0.8 \%)$ and lysine $(4.1 \%)$ content while that of tryptophan was rather high (1.15\%) (Table 4). Juno seeds analysed by Buraczewska et al. (1993) contained much more lysine $(5.1 \%)$, somewhat less methionine and cystine $(2.91 \%)$ and considerably less tryptophan $(0.78 \%)$. According to Peretiatkowicz et al. (1988) another variety of yellow lupin had a similar lysine content $(4.43 \%)$ whereas lower level of methionine and cystine $(2.12 \%)$. Some of the differences quoted may result from slightly different analytical procedures, mainly hydrolysis conditions. In our studies the index of

TABLE 4

Amino acid composition of protein, $\mathrm{g} / 16 \mathrm{~g} \mathrm{~N}$

\begin{tabular}{lcccc}
\hline Amino acid & Whole seeds & Hulled seeds & Cotyledons & Hulls \\
\hline HIS & 3.34 & 2.83 & 3.02 & 2.37 \\
LYS & 4.13 & 4.02 & 4.06 & 4.83 \\
PIIE + TYR & 5.90 & 6.28 & 5.73 & 6.29 \\
MET + CYS & 2.81 & 3.05 & 2.70 & 2.30 \\
THR & 2.65 & 2.61 & 2.54 & 3.16 \\
TRY & 1.15 & 0.90 & 0.92 & 1.81 \\
ILE & 3.44 & 3.48 & 3.25 & 3.46 \\
LEU & 6.88 & 7.03 & 6.62 & 5.67 \\
VAL & 3.25 & 3.08 & 3.02 & 4.30 \\
CS (MET) & 20.0 & 18.3 & 19.3 & 19.8 \\
EAAI & 60.0 & 58.9 & 56.6 & 63.8 \\
\hline
\end{tabular}


Results of nutritional experiment with various protein sources in diet

\begin{tabular}{lcccc}
\hline Specification & & Casein & Whole lupin seeds & Hulled lupin secds \\
\hline Feed intake', & $\mathrm{g}$ & $282.0 \pm 14.2$ & $283.6 \pm 10.0$ & $273.6 \pm 7.8$ \\
Body weight gain ${ }^{1}$, & $\mathrm{g}$ & $89.9^{\mathrm{A}} \pm 4.40$ & $60.3^{\mathrm{B}} \pm 2.70$ & $58.9^{\mathrm{B}} \pm 2.50$ \\
PER & & $3.02^{\mathrm{A}} \pm 0.10$ & $2.02^{\mathrm{B}} \pm 0.06$ & $2.05^{\mathrm{B}} \pm 0.05$ \\
Protein digestibility: & & & & \\
- apparent digestibility, & $\%$ & $89.2^{\mathrm{a}} \pm 0.3$ & $83.2^{\mathrm{b}} \pm 1.0$ & $82.3^{\mathrm{b}} \pm 0.5$ \\
- true digestibility, & $\%$ & $93.0^{\mathrm{a}} \pm 0.4$ & $86.8^{\mathrm{b}} \pm 1.0$ & $86.2^{\mathrm{b}} \pm 0.6$ \\
Relative organ weight ${ }^{2}:$ & & & & \\
- liver, & $\mathrm{g}$ & $4.50^{\mathrm{A}} \pm 0.10$ & $3.76^{\mathrm{B}} \pm 0.07$ & $3.88^{\mathrm{B}} \pm 0.11$ \\
- small intestine, & $\mathrm{g}$ & $3.43^{\mathrm{a}} \pm 0.16$ & $3.62^{\mathrm{ab}} \pm 0.17$ & $3.98^{\mathrm{b}} \pm 0.22$ \\
\hline
\end{tabular}

${ }^{1}$ Mean value with their standard errors during 4-week experiment

${ }^{2}$ Organ weight in $\mathrm{g} / 100 \mathrm{~g}$ body weight after 4-week nutritional experiment

Means with the same superscripts within a column are not significantly different by Duncan's multiple range test: $\mathrm{a}, \mathrm{b}-\mathrm{P} \leqslant 0.05 ; \mathrm{A}, \mathrm{B}-\mathrm{P} \leqslant 0.01$

essential amino acids (EAAI) was 60 and was close to the upper values found by Matyka et al. (1985) in 32 samples of yellow lupin seeds. The limiting amino acid was methionine ( $\mathrm{CS}=20$ ). In hulled seeds, like in the cotyledons, tryptophan content decreased by about $20 \%$ and so did the content of lysine and methionine though to a less extent. This was the result of greater content of these amino acids in the removed seed coat: $1.80 \%$ of tryptophan and $4.83 \%$ of lysine. Removing of the seed coat having higher EAAI (63.8), reduced this index in hulled seeds to 58.9 as compared with whole seeds $(60)$.

Substituting whole with hulled seeds in diet for rats did not affect the diet intake or protein efficiency ratio (Table 5). In both groups of rats, PER exceeded 2 and was slightly lower from the values reported by Prieto and Aguilera (1985) for white lupin. Coefficients of apparent and true digestibility were high and exceeded the values reported by Prieto and Aguilera (1985). Similar values of the coefficients for various lupin varieties were found by Eggum et al. (1993). Inclusion of whole or hulled lupin seed did not result in the enlargement of the liver as compared with rats fed casein diet. Liver weight, being in our experiments $3.8-3.9 \mathrm{~g} / 100 \mathrm{~g}$ rat body weight, was markedly lower than the values found by Pastuszewska et al. (1993) (4.43 g). In the latter experiment, however, the increase in rat body weight was much higher compared to those obtained for casein diet in our experiments.

The results of the study showed that hulling evidently affected the chemical composition of seeds resulting among others in an increase of protein content and decrease in fibre content. However, hulling of seeds did not increase 
digestibility or nutritional value of seed proteins in rats. In a parallel experiment by Flis et al. (1993), the nutritional value of whole and dehulled lupin seeds in diets for pigs was assessed.

\section{REFERENCES}

Aguilera J.F., Molina E., Prieto C., 1985. Digestibility and energy value of sweet lupin seed (Lupinus albus var. multolupa) in pigs. Anim. Feed Sci. Technol. 12, 171-178

AOAC, 1990. Official Methods of Analysis of the Association of Official Analitical Chemists, 5th Ed., Chapter 32

Brillouet J.-M., Riochet D., 1983. Cell wall polysaccharides and lignin in cotyledons and hulls of seeds from various lupin (Lupinus L.). J. Sci. Food Agric. 34, 861-868

Buraczewska L., Pastuszewska B., Smulikowska S., Wasilewko J., 1993. Response of pigs, rats and chickens to dietary level of alkaloids of different lupin species. In: Recent advances of research in antinutritional factors in legume seeds. T.F.B. van der Poel., J. Huisman, H.S. Saini (Editors), Wageningen Pers, EAAP Publication No. 70, 371-376

Donovan B.C., McNiven M.A., MacLcod J.A., Anderson D.M., 1991. Protein quality of two cultivars of lupin seeds evaluated in weaning rats. Anim. Feed Sci. Technol. 33, 87-95

Eggum B.O., 1973. A study of certain factors influencing protein utilisation in rats and pigs. Baretn. 406. National Institute of Animal Science, Cøpenhagen, pp. 172

Eggum B.O., Tomes G., Beames R.M., Datta F.U., 1993. Protein and energy evaluation with rats of seed from 11 lupin cultivars. Anim. Feed Sci. Technol. 43, 109-119

Evans A.l., Cheung P.C.-K., 1993. The carbohydratc composition of cotyledons and hulls of cultivars of Lupinus angustifolius from Western Australia. J. Sci. Food Agric. 61, 189-194

Flis M., 1993. Nutritive value of seeds of new varieties of field bean and yellow lupin for fattening pigs (in Polish). Acta Acad. Agric. Tech. Olst. Zoot., 38, Suppl. A, pp. 47

Flis M., Tywończuk J., Sobotka W., Lewicki Cz., Lipiński K., 1994. The effect of dehulling or fat and lysine and methionine supplementation on nutritive value of yellow lupin seeds for pigs (in Polish). (in press)

Feldheim W., 1990. Use of lupins as sources of lipids and dietary fibre in human nutrition. Proceedings of 6 th International Lupin Conference. Temu-Pucon (Chile), pp. 124-131

Hirs C.H., Stein W.H., Moore S., 1954. The amino acid composition of ribonuclease. J. Biol. Chem. $211,9411.9500$

Just A., Fernandez J.A., Jørgensen H., 1993. The net energy value of dicts for growth in pigs in relation to the fermentative processes in the digestive tract and the site of absorption of the nutrients. Livest. Prod. Sci. 10, 171-186

Matyka S., Burczyńska-Niedzialek A., Korol W., 1985. Chemical composition of the different species of legumes grown in Poland (in Polish). Biul. inf. Przem. Pasz. 1, 3-10

Múzquiz M., Rey C., Cuadrado C., 1992. Effect of germination on oligosaccharide content of lupin species. J. Chromatogr. 607, 349-352

Múzquiz M., Burbano C., Gorospe M.J., Ródenas I., 1989. A chemical study of Lupinus hispanicus seed - toxic and antinutritional components. J. Sci. Food Agric. 47, 205-214

Opieńska-Blauth J., Charęzińska M., Berbeć H., 1993. A new rapid method of determining tryptophan. Anal. Biochem. 6, 60-76

Pastuszewska B., 1985. Factors affecting nutritive value of field bean, pea and lupin for monogastric animals (in Polish). Thesis, Ossolineum, Wrocław, pp. 140 
Pastuszewska B., Jach K., Perkowski W., 1989. The effect of lupin alkaloids on growth performance of rats and chicken. In: Recent advances of research in antinutri-tional factors in legume seeds. J. Huisman , T.F.B. van der Poel. I.E. Liner (Editors), Pudoc, Wageningen 202-205

Peretiatkowicz M., Wojtaszek P., Michalski Z., Gulewicz K., 1988. The amino acid composition of seed proteins and fractions of different lupine species. Bull. Pol. Acad. Sci. Ser. Biol. 36, 1-9

Prieto C., Aguilera J.F., 1986. The effect of the supplementation with methionine and lysine of diets based on lupin seed (Lupinus albus var. multolupa) on protein and energy utilisation in growing rats. J. Anim. Physiol. Anim. Nutr. 55, 239-246

Rakowska M., Szkiłłądziowa W., Kunachowicz H., 1978. Biological value of food protein (in Polish). WNT, Warszawa, pp. 204-205

Rutkowska U., 1981. Methods for estimation of composition and nutritive value of food (in Polish). PZWL, Warszawa 204-205

Saini H.S., 1989. Legume seed oligosaccharides. In: Recent advances of rescarch in antinutritional factors in legume seeds. J. Huisman, T.F.B. van der Poel, I.E. Liner (Editors), Pudoc, Wageningen, pp. 329-341

Schram E.S., Moore E., Bigwood J., 1954. Chromatographic determination of cystine as cysteic acid. Biochem. J. 57, 33-35

Skolik J., Wiewiórowski M., 1959. Photometric micromethod for estimation of lupin alkaloids (in Polish). Rocz. Chemii 33, 461-466

Taverner M.R., Curic D.M., Rayner C.M., 1983. A composition of the extend and site of energy and protein digestion of wheat, lupin and meat-and-bone meal by pigs. J. Sci. Food Agric. 34, 122-128

Trugo L.C., Almeida D.C.F., Gross R., 1988. Oligosaccharide content in the seeds of cultivar lupins. J. Sci. Food Agric. 45, 21-24

\section{STRESZCZENIE}

Sklad chemiczny liścieni $\mathrm{i}$ lupiny nasiennej oraz wartość pokarmowa całych $\mathrm{i}$ obłuszczonych nasion lubinu żóltego

Usunięcie okrywy nasiennej, poprzez mechaniczną separację tej frakcji z nasion gniecionych, spowodowało wzrost zawartości białka $\mathrm{z} 41,6$ do $52,4 \%$ i zmniejszenie zawartości włókna pokarmowego z $28,4 \%$ do $15,9 \%$ w stosunku do całych nasion łubinu żółtego odmiany Juno. Skład chemičny, w tym zawartość alkaloidów $(0,15 \%)$, włókna pokarmowego $(15,9 \%)$ oraz $\alpha$-galaktozydów $(11,66 \%)$ nasion obłuskanych, byl zbliżony do liścieni lubinu, uzyskanych przez ręczny rozdzial frakcji nasion. Ze względu na większą zawartość $w$ okrywie nasiennej niektórych aminokwasów egzogennych, a głównie tryptofanu i lizyny, obłuskanie nasion zmniejszyło wskaźnik EAAI z 60,0 w nasionach całych do 58,9 w nasionach obłuskanych. Zastąpienie w diecie dla szczurów śruty $\mathrm{z}$ całych nasion łubinu śrutą z nasion obłuskanych nie zwiększyło współczynnika strawności białka ogólnego (odpowiednio 86,8 i $86,2 \%$ ) oraz wydajności wzrostowej białka, mierzonej wskaźnikiem PER (odpowiednio 2,02 i 2,05). 